\title{
Study on the Vertical Distribution of Epiphytic Bryophytes on Beech Trees, Fagus crenata Blume*
}

\author{
by Yoshiwo HoRIKawa \& Satoshi NaKanishi ${ }^{* *}$ \\ 堀川芳雄・中西哲：ブナに着生する碳苔類の垂直分布について
}

Received November 10, 1955

The epiphytes in the coniferous, evergreen and deciduous forests in the mountain area of Japan have a wide range of development and grow in considerable abundance. This is especially true of bryophytes and lichens. Ecological studies of epiphytic communities in the forests of Japan have been incomplete, because there are many unavoidable difficulties in collecting the data in the field works.

In both Europe and North America, attention has been attracted to the subject of epiphytic bryophyte communites to a considerable extent but only a few reports on their distribution on the supporting-tree have been published. ${ }^{4,6)}$ Recently,M. E. Hale2) reported that "the cryptogams have a definite pattern of distribution along the trunk with each species reaching a maximum value of constancy at one level".

When the above information on the vertical distribution of epiphytes is considered from a synecological standpoint, it may be understood that the floristic composition of the epiphytic community is not uniform but different in each part of the supporting-tree, e. g. the trunk base, the trunk, the crown base and the crown.

In the present paper, the writers report the results obtained from a study of the vertical distribution of epihytic bryophytes on the trunks of Fagus crenata Blume in the two different places, namely the mounain-ridge and the mountainside places***, of Mt. Kammuri in the western part Hiroshima Prefecture.

\section{General View of the Two Places}

This study was made during the summer of 1953 on ten beech trees in the mountain-ridge at an elevation of about $1320 \mathrm{~m}$ above sea level and on six trees in the mountain-side at an elevation of $1140 \mathrm{~m}$ above sea level, which is considered to

* Contributions from the Phytotaxonomical \& Geobotanical Laboratory. Hiroshima University N. Ser. No. 30. This paper was read by the authors at the annul meeting of the Botanical Society of Japan (Kanazawa, Oct. 1953).

** Botanical Institute, Faculty of Science, Hiroshima University, Hiroshima.

*** Henceforth, the term mountain-ridge place and mountain-side place will represent only as mountain-ridge and mountain-side in this paper. 
be the lower limit of the beech forest in this district.

The averge height of investigated trees is about $15.5 \mathrm{~m}$ (the minimum is $13.5 \mathrm{~m}$ and the maximum $19 \mathrm{~m}$ ) in the mountain-ridge, while in the mountain-side it is about $17 \mathrm{~m}$ (the minimum is $14 \mathrm{~m}$ and the maximum $20 \mathrm{~m}$ ). The average value of D.B.H. (Diameter Breast Height) is $0.27 \mathrm{~m}$ and $0.32 \mathrm{~m}$ in the mountain-ridge and the mountain-side respectively. Branching of the boughs begins at a height of $6 \mathrm{~m}$ in the former and $6.5 \mathrm{~m}$ in the latter.

The forest community in the mountain-ridge is generally composed of the following specices: in the arboresent layer, Fagus crenata BLUME, Acer sieboldianum MIQUEL; in the fruticose layer, Lindera umbellata THUNB., Symplocos chinensis (LOUR). DRUCE.; in the herbaceous layer, Carex foliossima FR. SCHM., C. multifolia OHWI. On the other hand, in mountain-side,Fagus crenata BLUME aud Quercus mongolica var. grosseserrata (BLUME) REHD- et WILS. are dominant in the arborescent layer, a:d Sasa veitchti (CARR.) REHD. is the characteristic species of the herbaceous layer, while in the frutiose layer there is no dominant species at all.

\section{Methods and Treatment of Data}

When the sample trees were selected for the purpose of our study the necessary considerations were paid to select them lest some trees in a small limited area should be the reprsentative trees of the whole area. Then, the trees were selected from several plots in the whole area.

And the studies were confined to living trees having no liana on their trunks and those with more straight trunks.

The epiphytic community on each supporting-trees is sampled by the following five cylindrical quadrats: from the ground to $0.5 \mathrm{~m} ; 2.5 \mathrm{~m}$ to $3.5 \mathrm{~m} ; 5.5 \mathrm{~m}$ to $6.5 \mathrm{~m}$; $8.5 \mathrm{~m}$ to $9.5 \mathrm{~m}$; and $11.5 \mathrm{~m}$ to $12.5 \mathrm{~m}$, and the names of the bryophytes occuring in each quadrat were recorded on data sheets. The vertical extent of each cylindrical quadrat is one meter except the trunk base and, although the area of each quadrat varies according to the diameter of the trunk, the number of species in a quadrat seems not to be governed by the variation of the area's size.

The following coincidental relationship of the situation is recognized between the international quadrats and the parts of the supporting-tree.

$\begin{array}{cl}\text { Quadrats } & \text { Parts of the supporting tree } \\ \text { From the ground to } 0.5 \mathrm{~m} & \text { Trunk base } \\ 2.5-3.5 \mathrm{~m} & \text { Trunk } \\ 5.5-6.5 \mathrm{~m} & \text { Upper trunk or Grown base } \\ 8.5-9.5 \mathrm{~m} & \text { Crown } \\ 11.5-12.5 \mathrm{~m} & \text { Upper crown }\end{array}$

The occurrence of bryophytes on all investigated supporting-trees, regardless of each quadrat, is best characterized as Presence, by assigning the rank of " stand" 
to a single investigated tree. The data obtained from quadrats at the same level are here given as Constancy, although the sample areas vary in the total size but not in the vertical extent. And the degree of vertical distribution of every species, obtained from the average value of the frequency which is decided by dividing the number of occurred quadrats by the total number of quadrats in a supporting-tree, is represented by the following five indexes: I occurring below $20 \%$, II from $21 \%$ to $40 \%$, III from $41 \%$ to $60 \%$, IV from $61 \%$, to $80 \%$, of average frequency.

\section{Results}

1. The state of the vertical distribution of epiphytic bryophytes in the mountain.ridge.

Of 41 species of epiphytic bryophytes counted in the mountain-ridge, 32 species. are mosses and the rest hepatics. The presence, constancy and the degree of vertical distribution of the major species are given in Table 1. In the mountain-ridge, Boulaya mittenii, Frullania moniliata subsp. obscura and Macrosporiella dozyoides, as a whole, are dominant and the physiognomy of epiphytic communities in the beech forest is characterized by the growth-forms of these species.

According to the value of constancy on different levels, the species can be divided into four distributional types, though they are not construed as rigid categories. The state of the vertical distribution of typical species belonging to each distributional type is illustrated in Fig. 1.

The occurrence of the first type is generally restricted to the trunk base level

Type 4

\section{Frullania usamiensis}

Ulota crispa

Type 3

Okamuraea cristata

Frullania moniliata subsp. obscura

Boulaya mitttenii

Type 2

Pterobryum arbuscula

Neckera konoi

Macrosporiella dozyoides

Type 1

Themnium sandei

Orthodicranum hakkodense

Height (m.)

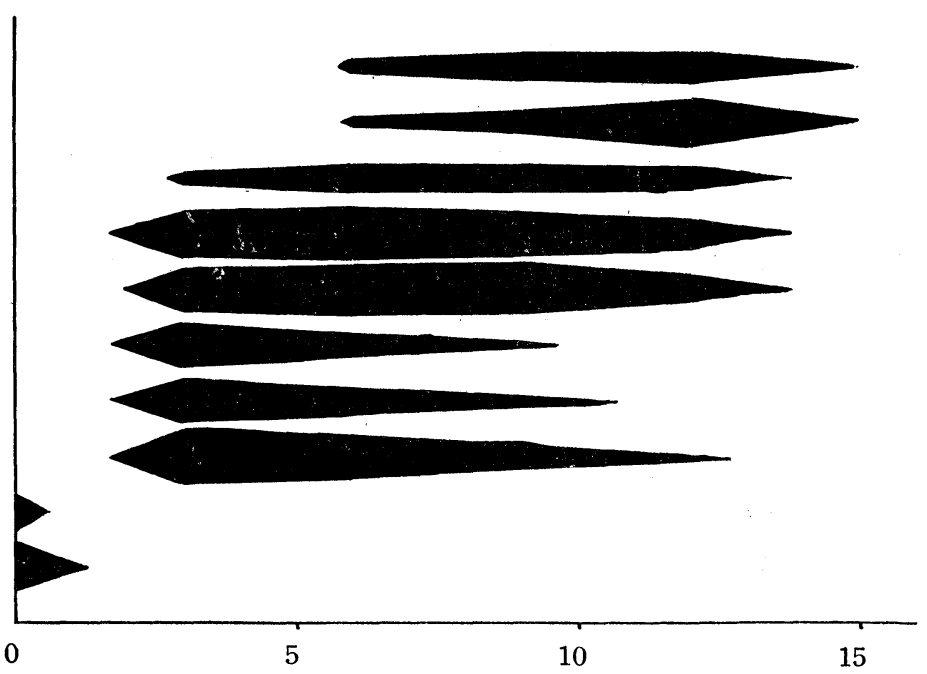

Part of the tree

Trunk-base Trunk Crown-base Crown Upper-crown

Fig. 1. Diagram showing the state of the vertical distribution of typical species belonging to respective distributional types. 
Table 1. Major species of epiphytic bryophytes occurring on beech trees in the mountain-ridge.

\begin{tabular}{|c|c|c|c|c|c|c|c|c|}
\hline \multirow[b]{2}{*}{$\begin{array}{c}\text { Growth } \\
\text { forms }\end{array}$} & \multirow[b]{2}{*}{ Species } & \multirow[b]{2}{*}{$\begin{array}{c}\text { Presence } \\
\%\end{array}$} & \multicolumn{5}{|c|}{$\frac{\text { Constancy } \%}{\text { Quadrats }}$} & \multirow[b]{2}{*}{$\begin{array}{c}\text { Degree of } \\
\text { vertical } \\
\text { distribution }\end{array}$} \\
\hline & & & 0 & \begin{tabular}{|l}
2.5 \\
$\widetilde{\tau}$ \\
$3.5 \mathrm{~m}$
\end{tabular} & \begin{tabular}{|l|}
2 uadrat \\
$\underset{5.5}{\sim}$ \\
$6.5 \mathrm{~m}$
\end{tabular} \mid & $\begin{array}{l}8.5 \\
\widetilde{\sim} \widetilde{m}\end{array}$ & $\left|\begin{array}{c}11.5 \\
\sim \\
12.5 \mathrm{~m}\end{array}\right|$ & \\
\hline $\mathbf{C}$ & Orthodicranum hakkodense & 80 & 80 & 一 & 一 & - & 一 & I \\
\hline FS & Anomodon ferrugineus & 80 & 80 & - & - & - & 一 & I \\
\hline $\mathbf{D}$ & Thamnium Sandei & 50 & 50 & - & 一 & - & 一 & I \\
\hline $\mathbf{D}$ & Dolichomitriopsis diversiformis & 40 & 40 & 一 & 一 & 一 & 一 & I \\
\hline Sf & Homalia joponica & 40 & 40 & 一 & 一 & 一 & 一 & I \\
\hline $\mathbf{M}$ & Plagiothecium denticulatum & 40 & 40 & 一 & 一 & 一 & 一 & I \\
\hline$\$ f$ & Fissidens gymnogynus & 30 & 30 & - & 一 & - & 一 & $\mathrm{I}$ \\
\hline Sf & Plagiochila ovalifolia & 30 & 30 & 一 & 一 & 一 & 一 & I \\
\hline $\mathbf{M}$ & Brachythecium plumosum & 30 & 30 & - & 一 & - & 一 & I \\
\hline $\mathbf{L p}$ & Metzgeria furcata & 30 & 30 & 一 & - & 一 & 一 & $\mathrm{I}$ \\
\hline $\mathbf{F s}$ & Macrosporiella dozyoides & 100 & 一 & 100 & 80 & 40 & 10 & III \\
\hline Bf & Neckera konoi & 90 & - & 80 & 50 & 20 & - & II \\
\hline Bf & Pterobryum arbuscula & 80 & - & 80 & 40 & 10 & 一 & II \\
\hline $\mathbf{F s}$ & Anomodon giraldii & 70 & 40 & 50 & 30 & 10 & 一 & II \\
\hline $\mathbf{H p}$ & Radula sp. (complanata?) & 60 & 一 & 20 & 40 & 一 & 一 & I \\
\hline $\mathbf{T p}$ & Dicranum fauriei & 50 & 一 & 50 & 30 & 10 & 20 & II \\
\hline Hp & Madotheca vernicosa & 40 & 10 & 30 & - & 一 & - & $\mathrm{I}$ \\
\hline Fs & Miyabea furticella & 40 & - & 30 & 30 & 一 & - & I \\
\hline Bf & Neckera yezoana & 30 & 10 & 20 & - & 一 & 一 & I \\
\hline $\mathbf{D}$ & Dolichomitra cymbifolia & 20 & - & 20 & 20 & 一 & 一 & I \\
\hline $\mathbf{H p}$ & Madotheca ulophylla & 20 & 一 & 10 & 一 & 10 & - & $\mathrm{I}$ \\
\hline Bf & Bissetia lingulata & 20 & 一 & 20 & 20 & 一 & 一 & $I$ \\
\hline Fs & Boulaya mittenii & 100 & 一 & 80 & 90 & 90 & 60 & IV \\
\hline Hp & Frullania moniliata subsp. obscura & 100 & 一 & 80 & 100 & 80 & 50 & III \\
\hline Fs & Okamuraea cristata & 90 & - & 20 & 50 & 50 & 40 & III \\
\hline $\mathbf{H p}$ & Frullania japonica & 60 & 一 & 30 & 10 & 30 & 20 & $\mathrm{I}$ \\
\hline Fs & Macrosporiella scabriseta & 50 & - & 10 & 30 & 40 & 20 & II \\
\hline cp & Ulota crispa & 90 & 一 & 一 & 20 & 40 & 80 & $\mathrm{I}$ \\
\hline $\mathbf{H p}$ & Frullania usamiensis & 90 & 一 & - & 20 & 50 & 60 & $\mathrm{I}$ \\
\hline $\mathbf{F s}$ & Macromitrium brachycladulum & 60 & 一 & 一 & 10 & 20 & 30 & I \\
\hline
\end{tabular}

where the humus layer shows a considerable development and little change of climatic factors is considered. Species of this group are Orthodicranum hakkodense, Anomodon ferrugineus, Thamnium Sandei, Dolichomitriopsis diversiformis, Homalia japonica, etc. The second type is the bryophytes which show the greatest value of constancy in the part between $2.5 \mathrm{~m}$ and $3.5 \mathrm{~m}$ in height, where these species find the fitful condition for their thriving, and their value of constancy gradually becames smaller in either upper parts or lower parts. Macrosporiella dozyoides, Neckera konoi, Pterobryum arbuscula and Anomodon giraldii are typical species of this group. 
The type 3 includes the bryophytes which occur with the maximum value of constancy in the part between the upper trunk and the crown and still show a relatively high constancy even in the upper crown but not occur in the trunk base. Macrosporiella scabriseta, Frullania moniliata subsp. obscura, Boulaya mittenii and Okamuraea cristata belong to this group. The members of the last type show the greatest value of their eonstancy in the upper crown, and are usually absent below the trunk. They are Ulota crispa, Macromitrium braccycladulum and Frullania usamiesis.

2. The state of the vertical distribution of epiphytic bryophytes in the mountain-side.

In the mountain-side, 12 species of mosses and 2 species of hepatics were found. This number is about one third of the total number of species in the mountainridge. The presence, constancy and the degree of vertical distribution of each species are shown in Table 2.

Table 2. Species of epiphytic bryophytes occurring on beech trees in the mountain-side.

\begin{tabular}{|c|c|c|c|c|c|c|c|c|}
\hline \multirow{3}{*}{$\begin{array}{l}\text { Growth } \\
\text { forms }\end{array}$} & \multirow[b]{3}{*}{ Species } & \multirow{3}{*}{$\begin{array}{c}\text { Presence } \\
\%\end{array}$} & \multirow{2}{*}{\multicolumn{5}{|c|}{$\begin{array}{c}\text { Constancy } \% \\
\text { Quadrats }\end{array}$}} & \multirow{3}{*}{$\begin{array}{l}\text { Degree of } \\
\text { vertical } \\
\text { distrifbution }\end{array}$} \\
\hline & & & & & & & & \\
\hline & & & $\begin{array}{l}0 \\
0.5 \mathrm{~m}\end{array}$ & \begin{tabular}{|l|}
2.5 \\
$3.5 \mathrm{~m}$ \\
\end{tabular} & $\begin{array}{l}5.5 \\
6.5 \mathrm{~m}\end{array}$ & $\begin{array}{l}8.5 \\
9.5 \mathrm{~m}\end{array}$ & $\left|\begin{array}{c}11.5 \\
\sim \widetilde{\sim} \\
12.5 \mathrm{~m}\end{array}\right|$ & \\
\hline $\mathbf{D}$ & Dolichomitriopsis diversifomis & 83 & 83 & - & - & 一 & -1 & I \\
\hline M & Brachythecium plumosum & 50 & 50 & - & 一 & 一 & - & $\mathrm{I}$ \\
\hline Fs & Anomodon giraldii & 33 & 33 & - & - & - & - & I \\
\hline $\mathbf{M}$ & Thuidium cymbifolium & 17 & 17 & - & - & 一 & - & I \\
\hline Bf & Neckera yezoara & 17 & 17 & 17 & 一 & 一 & - & II \\
\hline Hp & Frullania usamiensis & 67 & - & 33 & 50 & 17 & 一 & $\mathrm{I}$ \\
\hline Fs & Okamuraea crtstata & 50 & - & 50 & 33 & - & 一 & I \\
\hline Fs & Macrosporiella dozyoides & 33 & 一 & 33 & 17 & - & 一 & II \\
\hline Fs & Macrosporiell scabriseta & 33 & 一 & 33 & 一 & 一 & - & $\mathrm{I}$ \\
\hline $\mathbf{H p}$ & Frullania moniliata subsp. obscura & 33 & - & 33 & - & 一 & - & I \\
\hline Fs & Boulaya mittenii & 33 & 一 & 33 & 17 & - & - & $\mathrm{I}$ \\
\hline Bf & Neckera konoi & 17 & 一 & 17 & 17 & 一 & 一 & II \\
\hline $\mathbf{F s}$ & Anomodon abbreviatus & 17 & - & 17 & 一 & 一 & - & I \\
\hline $\mathbf{c p}$ & Ulota crispa & 100 & 17 & 67 & 67 & 33 & 17 & II \\
\hline
\end{tabular}

In the place, it is clear that the vertical distribution of every species is more narrowly limited than in the mountain-ridge. And it is also obvious that the situation where the species, which can be found in both places, grow in the best condition is lower in the mountain-side than in the ridge. It must be noticed with an interest that Ulota crispa growing in the maximum constacy in the upper crown part of the supporting-trees in the mountain-ridge, appears, in the mountain-side, in all parts of the supporting-trees, though its constancy is smaller.

As mentioned above, there are several obvious differences in the growing state 
of the vertical distribution between the mountain-ridge and the mountain-side. Consequently, the distributional pattern which was observed in the mountain-ridge seems to be not always the same to that of the mountain-side; that is, one is inapplicable to the other. It may be more appropriate to divide the species in the mountainside into two groups: one whose maximum constancy is at the trunk part, and the other at the trunk base.

3. A comparative consideration of the vertical distribution in two places viewed from the stand point of growth-form.

The relative number (\%) and the average constancy of species belonging to each growth-form type of epiphytes ${ }^{3}$ are obtained with respect to every parts of the supporting-trees in two places, and the resultare shown in Fig. 2. And the spectrum of growth-forms in both places is shown in Table. 3.

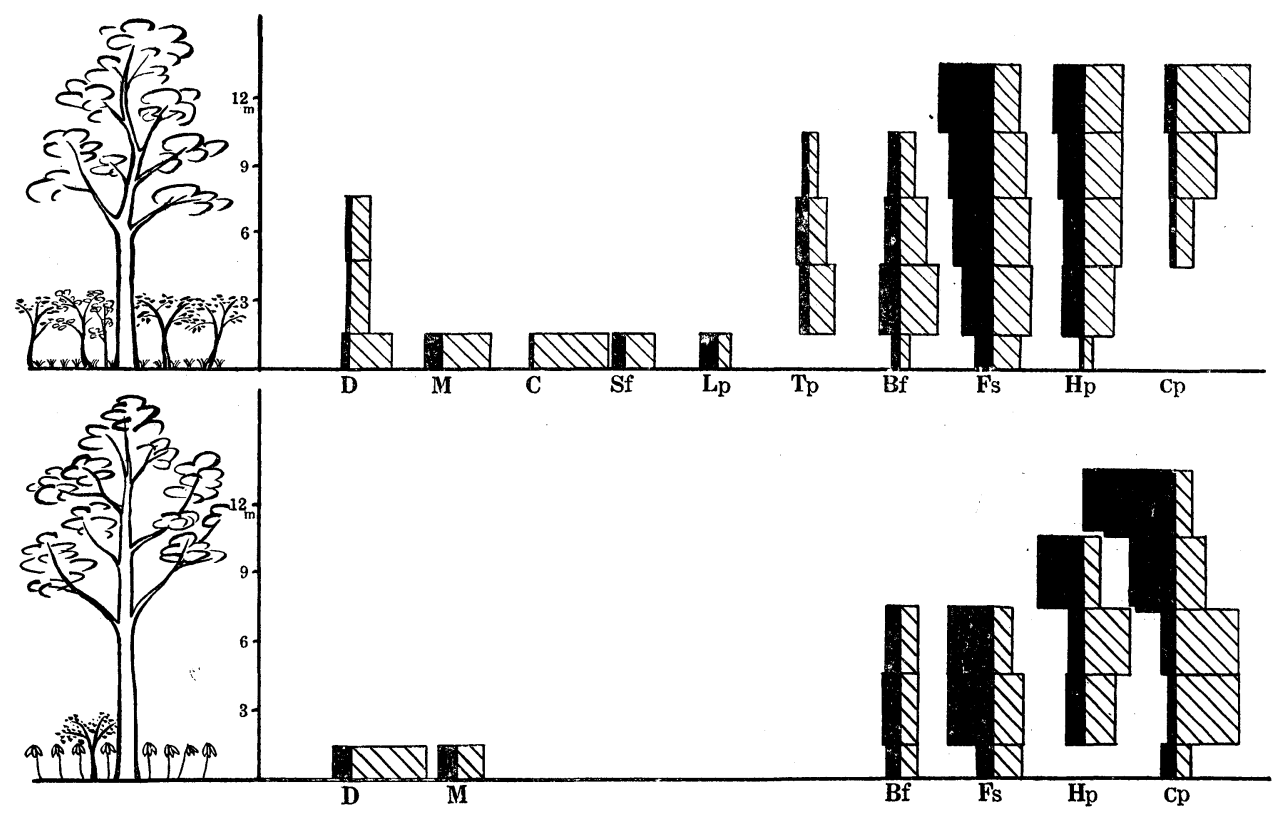

Fig. 2. This growth-from spectrum of epiphytic bryophytes in each part of the supporting-tree. The black portion indicates the relative number $(\%)$. and the portion with oblique line indicates the average constancy.

Table 3. The growth-form spectra of epiphytic bryophytes in two places.

\begin{tabular}{l|cccccccccc}
\hline Growth forms & $D$ & $M$ & $C$ & $S f$ & $E f$ & $L p$ & $T p$ & $F s$ & $H p$ & $c p$ \\
\hline Mountain-ridge & 7 & 10 & 2 & 7 & 12 & 10 & 5 & 29 & 15 & 2 \\
\hline Mountain-side & 7 & 14 & - & - & 14 & - & - & 42 & 14 & 7
\end{tabular}

The growth-forms such as carpet type (C), simple feather (Sf), loosely pressed mat type (Lp) and turf type (Tp), which occur in the mountain-ridge, are absent in 
the mountain-side. And the growth-form of small cushion type (cp), which is characteristic of the upper crown part in the mountain-ridge, has a wide vertical distribution in the mountain-side. The growth-form of fascicular and shrubby type (Fs) and hardly pressed mat type (Hp) are found in all parts of the supporting trees in the mountain-ridge, but are rather limited to the lower part of the trunk in the mountain-side.

The stems of plants classified into the growth-form of small cushion type (cp) are in close contact with each other and form the "moss ball" in appearance. It may be considered that this growth-form is more familiar to a dry condition than other growth-types. It may be considered that, contrary to the case in the mountainridge, the contrast been the vigorous growth of small cushion type (cp) and the dull growth of fasicular and shrubby type (Fs) and hardly pressed mat type (Hp) in the mountain-side is due to the dryness in there, which is immoderate to some extent, compared with that in the mountain-ridge.

\section{Discussion and Conclusion}

From our observations, it becomes clear that each species does not occur all over the supporting-tree but its occurrence is considerably confined to limited parts of the supporting-tree, in other words, each species has a definite pattern of the distribution which is peculiar to it. Thus, it is recognized that the epiphytic bryophyte community has a substantial tendency, which is noteworthy, to occur in zonal arranagement. The fact mentioned above shows that the respective parts of the supporting-tree have peculiar habitat conditions for the bryophytes to thrive. Therefore, it seems reasonable to say that it is an essential, indispensable method for the solution of ecological studies of epiphytic communities to divide the supporting-tree into several parts, as was already proposed by Ochsner5) and after-

Table 4. The zonal arrangement in two places.

\begin{tabular}{|c|c|c|c|c|c|}
\hline \multirow[b]{2}{*}{$\begin{array}{l}\text { Part of } \\
\text { the tree }\end{array}$} & \multirow[b]{2}{*}{ Height } & \multicolumn{2}{|r|}{ Mountain-ridge } & \multicolumn{2}{|r|}{ Mountain-side } \\
\hline & & $\begin{array}{c}\text { Main } \\
\text { growth } \\
\text {-forms }\end{array}$ & Major species & $\begin{array}{l}\text { Main } \\
\text { growtn } \\
\text {-forms }\end{array}$ & Major species \\
\hline $\begin{array}{l}\text { upper } \\
\text { crown }\end{array}$ & $\begin{array}{l}\text { above } \\
10 \mathrm{~m}\end{array}$ & $\begin{array}{l}\text { cp } \\
\mathbf{H p}\end{array}$ & $\begin{array}{l}\text { Ulota crispa } \\
\text { Frullania usamiensis }\end{array}$ & $\mathbf{c p}$ & \multirow[t]{2}{*}{ Ulota crispa (rare) } \\
\hline $\begin{array}{l}\text { crown } \\
\text { base }\end{array}$ & $5.5 \sim 9 \mathrm{~m}$ & $\begin{array}{l}\text { Hp } \\
\text { Fs }\end{array}$ & $\begin{array}{l}\text { Boulaya mittenii } \\
\text { Okamuraea cristata } \\
\text { Frullania moniliata } \\
\text { subsp. obscura }\end{array}$ & \multirow{3}{*}{$\begin{array}{l}\text { Fs } \\
\mathbf{H p} \\
\mathbf{c p} \\
\mathbf{D} \\
\mathbf{M}\end{array}$} & \\
\hline trunk & $2 \sim 5 \mathrm{~m}$ & $\begin{array}{l}\text { Bf } \\
\text { Fs }\end{array}$ & $\begin{array}{l}\text { Macrosporiella dozyoides } \\
\text { Neckera konoi } \\
\text { Pterobryum arbuscula }\end{array}$ & & $\begin{array}{l}\text { Ulota crispa } \\
\text { Frullania usamiensis } \\
\text { Okamuraea cristata }\end{array}$ \\
\hline $\begin{array}{l}\text { trunk } \\
\text { base }\end{array}$ & $\begin{array}{l}\text { below } \\
1 \mathrm{~m}\end{array}$ & $\begin{array}{l}\text { M } \\
\text { Fs } \\
\text { Sf } \\
\text { D }\end{array}$ & $\begin{array}{l}\text { Orthodicranum hakkodense } \\
\text { Anomodon ferrugineus } \\
\text { Thamnium sandei }\end{array}$ & & $\begin{array}{l}\text { Dolichomitriopsis diversiformls } \\
\text { Branchythecium plumosum }\end{array}$ \\
\hline
\end{tabular}


words emphasized by Braun-Blanquet ${ }^{1)}$

The state of zonal arrangement observed in the mountain-ridge differs from that in the mountain-side. The zonal arrangements in the two places are comparatively summarized in Table 4.

The epiphytic bryophyte community on the young beeches in the mountain-ridge is generally similar, in its floristic composition and physiognomical character, to that on the old beeches in the mountain-side. Then, it may be considered that the species found in the latter are the "pioneer" elements, as reported by E. Quarterman") in a early stage of the development of epiphytic community on the bark of beeches. However, judging from the fact that the average values of D. B. H. of investigated supporting-trees in the two places show little difference, the ages of beech forests in the two places are considered to be almost of the same. Therefore, such successional view point as mentioned above may be relegated to a subsidiary position of consideration for the present.

Thus, it follows probably that the notable differences of zonal arrangement between the two places may be due to the differences of climatic factors brought by the differences of the topographical conditions. The ridge of this mountain, being higher than the surrounding mountains, acts necessarily as a barrier rôle, where very moist air coming from the Sea of Japan in winter and from the Pacific Ocean (or the Setonaikai) in summer season is always kept. Consequently, the mountain-ridge of Mt. Kammuri is always kept in a comparatively damper condition than the mountain-side all the year round.

It seems to be natural to recognize that the epiphytic bryophyte communities in both places are in the stage of climax with its own peculiar composition according to the differences of climatic factors.

\section{Summary}

1. An investigation of 16 beech trees (Fagus crenata BLUME.) in the forest of Mt. Kammuri, located in the western part of Hiroshima Prefecture, was conducted to determine the vertical distribution of epiphytic bryophytes.

2. All species taken up in the investigation of the mountain-ridge are grouped into four distributional types: the groups of species showing their maximum flourishing (1) it the trunk base, (2) at the trunk, (3) at the upper trunk and crown base, (4) at the upper crown.

3. It recognized that the epiphytic bryophyte communities show a substantial tendency of the zonation in the vertical distribution observed in the supportingtrees.

4. There are some remarkable differences in the state of zonal arrangement between the mountain-ridge and the mountain-side. The comparative summarization of the zonal arrangement in each place is shown in Table 4.

5. It seems to be that differences in the state of zonal arrangement between 
the two places are mainly due to the difference of climatic factors brought by topographical conditions.

\title{
Literature cited
}

1) Braun-Blanquet, J. pflanzensoziologie. Grundzüge der Vegetaionskunde. 2 Auf Springer, Wien. (1951), (1 Aufl. 1928). 2) Hale, M.E. Ecology 33: 398-406 (1952). 3) Horikawa, Y. \& Nakanishi, S. Bull. Soc. Plant Ecology 3: 203-210 (1954). 4) Martin, M, Jour. Ecol. 26: 82-95 (1938). 5) Ochsner, F. Jahr. der St. Gall. Naturw. Gesell. 63: 1-108 (1927). 6) Phillips, E. A. Ecol. Monogr. 21: 301-316 (1951). 7) Quarterman, E. Bryologist 52: 152-165 (1949).

\section{速 報}

\section{Auxins and Free Sulfhydryl Groups in Relation to the Abscission of Cotyledon}

\author{
by Yasuo HotTA and Takahisa ÔTA*
}

\section{堀田康雄・太田敬久：生長素及び遊離 $\mathrm{SH}$ 基の子葉離脱における役わり}

\section{Received March 5, 1956}

Under our standard germination conditions $\left(27^{\circ} \mathrm{C}\right.$, room light; Knop's sol.) the abscission of cotyledons of a bean, Vigna sesquipedalis, occurs on the 7 th day of germination.

With a paper-chromatographic survey, it was confirmed that the substance positive to Avena-test in the cotyledon as well as in the hypocotyl is exclusively indole-acetic acid (IAA). In the epicotyl, however, abundant Avena-positive substances other than IAA were detected in the early stage of germination, which were replaced later by IAA.

As to the content in diffusible auxins, a maximum was seen on the $3 \mathrm{rd}$ day in the epicotyl, and in the hypocotyl, although less conspicuous, on the lst or 2nd day. When the plants were grown in the dark, the content in the epicotyl showed a monotonous increase for 7 days without any peak, and, notwithstanding this, the time of abscission of the cotyledon was not changed. Diffusible IAA was absent in the cotyledon, and no IAA appeared to diffuse from the cotyledon into the stem. These negative results were likely not to be due to the breakdown of IAA by IAAoxidase in the cotyledon tissues.

The ether-extractable IAA in the cotyledon and in the hypocotyl showed maxima on the lst day and on the 3rd, respectively, but that in the epicotyl showed a continuous increase. In the dark culture the extractable IAA content in these tissues showed a similar change to that in the room light culture. It was noted, however, that in the hypocotyl after the maximum was passed the content dropped

\footnotetext{
* Biological Institute, Faculty of Science, Nagoya University, Nagoya, Japan
} 